\title{
Strategic Transformation and Innovation towards Blue Ocean Creation in a Changing Corporate Reality
}

\author{
Andreas Karaoulanis \\ PhD student, Cardiff University, Greece
}

\begin{abstract}
The main scope of the paper is to underline the significance of change on a corporate level. Adapt and change is the cornerstone of survival in the industrial world. Everything is changing rapidly and companies need to understand that in order to survive and sustain their development they need to transform themselves. Innovating is the key towards transformation, thus change.

In this literary review, the author tries to present the correlation between the strategic transformation and the innovation in the form of open innovation and customers as innovators with the creation of blue oceans. The author argues that nowadays when companies facing multiple challenges due to the globalization, they need to implement such strategic approaches in order to transform their business via incremental changes. Although this approach is not a panacea, it is imperative to underline that can clearly create a strong competitive advantage for the companies in question and can be the springboard towards growth and sustainable development.
\end{abstract}

On the other hand, disruptive innovation can be the springboard towards such strategic implementation and can only be achieved via certain channels such as the customers as innovators and the open innovation approaches which although they are not widely spread nowadays, they can be the springboard towards a better future for the global economy.

The correlation between such aspects and their implications in the companies' strategic approach it is a very controversial issue which needs a further investigation on the basis of a future research.

Keywords: users, innovators, disruptive innovation, blue oceans, lean, open innovation, transformation.

JEL Classification: M1, O1.

(C) The Author, 2018. This article is published with open access at Sumy State University.

\section{Introduction}

In contemporary markets, people are starting to get more into the meaning of "democratized innovation". By that expression we mean that users of products and services - both firms and individual consumers - are increasingly able to innovate for themselves (Eric von Hippel, 2005). This innovation approach offers so much to consumers/ customers as they can develop exactly what they want without relying on the companies or their agents to propose them what they should want. The whole scenery is completely different with what was happening in every single market for many decades till now.

\section{Users as Innovators. A Disruptive Approach}

As users' needs for products are highly heterogeneous in many fields (Franke and Reisinger 2003, cited in Von Hippel, 2005), the need for products' customization is getting bigger by the years. Specific industries, like the software one is a very characteristic example of how things work that way. People need specific customized solutions for themselves and of course, for their companies in terms of the software they want to purchase in order to get their job done. Customization is the corner stone of selling in the software industry. We all are familiar with examples like mobile data service (MDS) innovation on iOS and Google Android platforms. Such platforms provide toolkits in order to be able to facilitate the users' participation, aiming to create an ecosystem for sustainable innovation (Kankanhalli et al., 2015).

We can also see the trend in the computer hardware industry, where customers have nowadays the opportunity to build their own computer systems by buying a specific tower, a specific processor, hard disk etc. in order to cover their needs exactly in the way they want and of course gain some extra money which they would have lost if they would have chosen a fixed solution (i.e. a desktop or laptop computer which pre-built characteristics). 
As Thomke and Von Hippel, 2002) underlined, nowadays customers seem completely different and understanding their needs in order to give them what they want seems a difficult and quite complicated task. This is why the customer as innovator approach seems to gain ground in contemporary markets.

A characteristic paradigm of the huge trend that customers as innovators have nowadays is the banking example that Oliveira and Von Hippel (2011) depict in their research in the USA banking sector. They reached out to the result that an impressive 55\% of today's computerized commercial banking services were first developed and implemented by non-bank firms in order to help their own usage needs, while an equally impressive $44 \%$ of today's computerized retail banking services were first developed and implemented by individual service users rather than by commercial financial service providers. Such numbers are indicative of how the contemporary banking system, at least in terms of computerized services was developed. Customers (firms and individuals) were the big innovators towards growth via better services.

Everybody seem to be happy as all get exactly what they want. It is one thing to buy a pre-fabricated kitchen for your house and is a completely different thing to be able to construct the kitchen the way that will exactly fit your needs. Solutions like this are getting very popular nowadays and have a great impact in many industries strategic planning.

According to Nordlund et al. (2011), users as innovators is an approach based upon three pillars: users are both capable and willing to innovate, communities are important entities in this innovation process and users are willing to freely reveal their innovative ideas. The existence of these pillars are essential in the whole process and are capable of creating a very strong frame for the companies in question in order to be able to implement such an approach.

According to Luthje et al. (2005) user-innovators tend to almost always make use of what they call as "local information" a term which means information that is already in their possession or that is generated by themselves as members of the local community in order to develop the solutions needed towards their final innovation. Such information is very crucial as the user-innovators will finally gain their rewards from inhouse usage. Luthje et al. (2005), underline the importance of such kind of information as its usage from the user-innovators will be extremely helpful to them as it would serve them as a yardstick, which will help them in a degree to predict the general nature of the innovations they might develop.

Ogawa et al. (2013), underlines the significance of community innovators as they tend to help one another and reveal information about their innovative ideas more than usually independent innovators do. Consequently, their innovations tend to be adopted more often than those of independent innovators.

The importance of customers as innovators is also underlined by Pongtanalert \& Ogawa (2015), who stated that customers as innovators and especially the ones who are belonging to communities, can be exquisite collaborators with the firms that selling the goods in their quest for new ideas. Of course the extent to which such customers/ used as innovators can integrate their ideas and innovation characteristics to the firms' products depends on many characteristics, as they can be classified in three main groups, which according to a Japan survey that Pongtanalert \& Ogawa (2015) contacted in a sample of 579 user-innovators are social, revealing and silent innovators.

But such innovation coming from users can be defined as a disruptive one and can determine a company's growth and sustainable development over the years? Can such innovation create new market segments and deliver outstanding results by generating new products or by reforming existing ones in a way that can be used in a more or less adjacent markets? Such questions are quite vital and very important in forming companies' strategies towards the creation and implementation of their competitive advantage.

According to Zhexembayeva (2014), business nowadays facing a global shortage of resources of every kind. Scarcity should become central in companies' thinking and should be their key driver of strategic innovation. By adding scarcity into the innovation equation, we are going towards a lean perspective in terms of innovation. But this is the case with the users- innovators approach. It is a lean approach that serves exactly what Zhexembayeva (2014) depicts in her book. So, under that prism seems that such approach is a must in contemporary markets. 
Being lean and use strategies like the user-innovator one can lead you towards disruptive innovation ${ }^{1}$ with safety. According to Markides (2006), all disruptive innovations are not the same. Technological, businessmodel and new-to-the-world product innovation should be treated in a distinct way. The author suggests all these three distinct types of disruptive innovation although they may follow similar processes in order to invade the existing market space and share equally disruptive effects to market segments where they are applied, but finally they end in producing different kind of markets and having different managerial implications. (Markides, 2006).

So, from the above we can easily understand that the dynamics of such disruptive innovation methods have different endings although their philosophy seems the same. One way of disrupting things thus markets is the case that we are investigating thru this paper, the users as innovators case.

It is the author's prevalent idea that users as innovators is a strategic technique which thru the disruption that can cause will probably end to the creation of a blue ocean, thus a new market segment or a complete new market out of nowhere, especially when the existing market seems saturated. In other words, to create an uncontested market space and make competition irrelevant (Kim \& Mauborgne, 2005).

\section{Strategic Renewal and Open Innovation}

Strategic renewal is a very important aspect of strategy implementation, especially nowadays as we are living in a rapidly changing world. Strategic renewal is a set of practices that are very important in terms of guiding leaders by the right use of innovation into a new business era (Binns et al. 2013).

Another definition which is very interesting, states that "Strategic renewal is an evolutionary process associated with promoting, accommodating and utilizing new knowledge and innovative behavior in order to bring about change in an organization's core competencies and/or a change in its product market domain" (Burgelman, 1991; Huff et al., 1992; Hurst et al.,1989, cited in Floyd \& Lane, 2000: 155).

One key factor that characterizes strategic renewal as a means of strategy implementation, is that it involves making changes ahead of a crisis, something which means that decisions need to be taken before the crisis' advent. This results in many cases in senior management to face problems in terms of initiating the program, fund and lead it (Binns et al. 2013).

Strategic renewal in multinational corporations need to overcome the inertial forces that are embodied in the already established strategy of the organization in question and to close the gap which usually exists between its existing core competencies and the evolving basis of the company's competitive advantage, in order to be successful (Burgelman, 1991, 1994; Huff, Huff, \& Thomas, 1992; Hurst, Rush, \& White, 1989, cited in Floyd \& Lane, 2000).

Innovation seem to be a key factor that influences in a very high degree such strategic movements. The correlation between strategic renewal and some forms of innovation will be discussed in the following chapters.

\subsection{The three sub-processes of strategy renewal}

According to Floyd \& Lane (2000), strategic renewal is a complex process, therefore we can say that it consists of three sub- processes which are the following:

1. Competence definition;

2. Competence deployment;

3. Competence modification (Floyd \& Lane, 2000).

It is important here to underline that within each of these sub- processes, the role of the managers, regardless of their level (top, middle, operating level) differs in terms of their time horizon, the information's requirements and the core values (Floyd \& Lane, 2000).

Competence definition is the sub- process during which, managers encourage experimentation with new skills and exploration of new market opportunities (Floyd \& Lane, 2000).

\footnotetext{
${ }^{1}$ Disruptive innovation, is a term of art coined by Clayton Christensen, which describes a process by which a product or service takes root initially in simple applications at the bottom of a market and then relentlessly moves up market, eventually displacing established competitors (claytonchristensen.com, n.d.).
} 
Competence deployment is the synoptic process during which, managers deploy resources in order to be able to venture into new market segments or in order to reinforce the market position of an existing product (Hamel 8f Prahalad, 1989; Levinthal \& March, 1993; Mehra \& Floyd, 1998, cited in Floyd \& Lane, 2000: 156).

Finally, competence modification is the sub- process during which, managers recognize the need for change; question the organizational strategic approach and competencies and encourage emergent and adaptive behavior (Huff et al. 1992, cited in Floyd \& Lane, 2000: 156).

\subsection{The two basic types of strategic renewal}

According to Afarwal \& Helfat (2009), there are two basic types of strategic renewal that we can distinguish: (1) discontinuous strategic transformations and (2) incremental renewal.

Nowadays, major changes, i.e. technological etc. can cause multinational companies to alter one or even more aspects of their strategy and organization in general (Afarwal \& Helfat, 2009). But these are not the only reasons why a company may step into such transformation sequence. Other reasons towards the same direction are i.e. the company's primary market became saturated or is declining. When the company is stepping into such transformation channels, it is more than obvious that important parts of the company and its strategy will be replaced as they are affected strongly (Afarwal \& Helfat, 2009: 283). Thus, such transformations entail strategic renewal by default.

On the other hand, companies nowadays are not able to predict, especially with high precision, potential dramatic shifts that might occur in its external environment (Afarwal \& Helfat, 2009: 283). In a fast paced global environment, companies are under significant pressure in terms of whether they will be able to adapt to changes and sustain their business. It is obvious from the above that multinationals need to transform as everything around them changes so quickly. In order to adapt to such changes, they need to do major transformations. Such transformations due to their magnitude, may pose great difficulties to multinational companies, so a very interesting solution to this problem is to transform incrementally, in other words, to renew themselves continuously in order to keep pace with the changes around them (Afarwal \& Helfat, 2009: 283). This is the notion of incremental renewal and this is also an important aspect which can lead us to the notion of the term "ambidexterity", which according to Tushman \& O' Reilly (2008), is operating a company in a way that it can build its future new business, while operating its mature business in parallel. It is a combination of incremental transformation while keeping the old part of the business, which has not been transformed yet in operational status as well.

\subsection{Open Innovation. The springboard of strategy renewal}

Open innovation (OI) is a way to open up the innovation process (Huizingh, 2006). One of its most often used definition is "the use of purposive inflows and outflows of knowledge to accelerate internal innovation, and to expand the markets for external use of innovation, respectively" (Chesbrough et al. 2006, cited in Huizingh, 2006: 2).

Open innovation can be the lever towards strategy renewal as it can unleash powers that multinational corporations did not even imagine that they possess. Of course, there are differences between companies in terms of how they adapt OI. They vary according to (1) their innovation requirements, (2) the timing of the implementation, (3) their organizational culture (Mortara, L. \& Minshall, T., 2011).

Strategy renewal in large multinationals need knowledge and experience. As Chesbrough (2003, cited in Enkel et al. 2009: 311), stresses "Not all the smart people work for us. We need to work with smart people inside and outside our company". This notion of networking is the core idea of open innovation. Once the notion of interorganizational innovation/ collaboration will enter the industry, everyone who does not participate will face severe problems and will even loose his competitive advantage, as transformation will come via the exchange of knowledge and technology between companies (Saint Paul, 2003: 3, cited in Enkel et al. 2009: 311). Thus, extroversion is an important aspect in multinationals' transformation process.

\section{Blue Ocean Creation Via Company Transformation and Innovation}

Companies nowadays, after severe economic recessions and via the lack of resources that was described above, need to innovate and to create via their strategic movements new types of markets. The blue oceans. According to Kim and Mauborgne (2005), there are two types of markets, the existing ones which are characterized by intense competition and are called red oceans and the non- existing ones which are untouched and uncontested waiting to be discovered by the companies' strategists. They are called blue oceans. Users as innovators is a 
very powerful tool in the hands of contemporary companies in order to reach their blue oceans and create a new market space where they will have the power to pose their rules to all new comers. To make a long story short, they will create an impeccable competitive advantage for themselves which will drive them with safety towards their future.

Users as innovators is a breakthrough innovation which can enable the potential manufacturing unit to benefit from such user innovations in its new products development, while in parallel, the user profits from improved tools (Block et al, 2016). The result benefits all and creates a competitive advantage for the manufacturing unit.

On the other hand, another new approach has come the last couple of years to reveal a new approach in the correlation between user-innovators and the manufacturers. This approach, as Block et al. (2016) underline, is the approach, which emphasizes in the diversification between user-innovators and manufacturers as a new path way towards the commercialization of users- innovators.

As Block et al. (2016) state, there are specific synergies between users and manufactures regarding the need knowledge, the solution knowledge, marketing and financials. The benefits for both the two parts, are connected with tight bonds on the way the specific case's conditions are related to innovation, marketing, organization and financials. This is a very important implication for the manufacturing companies, which suddenly realize that "selling" their own users-innovation ideas, can jeopardize their competitive advantage (Block et al. 2016). That can lead manufacturing companies to lose the very same advantage that they gained in the first place via the users- innovators approach.

According to O' Reilly \& Tushman (2016), are underlining a very disturbing truth that companies nowadays regardless their magnitude, are shuttering more quickly than ever. The authors state that companies in order to avoid this new trend need to cultivate a way of ambidexterity in their core essence of business. In other words, to remain competitive in their niche markets, while also they must be victorious in new domains (markets or market segments) (O’ Reilly \& Tushman, 2016).

Additionally, multinational companies nowadays, after severe global economic recessions need to innovate and to create, via their strategic movements, new types of markets. According to Kim and Mauborgne (2005), there are two types of markets, the existing ones which are characterized by intense competition and are called red oceans and the non- existing ones which are untouched and uncontested waiting to be discovered by the companies' strategists. They are called blue oceans. Creating a blue ocean means renew your company in a way that it will create a new market out of nowhere, something which will give to the company the competitive advantage needed as an incumbent now, in order to sustain its business in the long run. Incumbent firms that strategically renew themselves prior or during the general market reform that will be attempted, enhance their chances of developing the size of their networks and revenue streams as well (Amankwah-Amoah et al. 2017; 2016).

It is also important to underline here that longevity of the business stems from the leaders' ability to develop as anticipated and to be able to respond to changes in close interaction with owners (Amankwah-Amoah et al. 2017; 2016). This is why the corporate management has such important role in transformation/ renewal strategy implementation.

\section{Conclusions}

Although this paper resulted in a simplified form of how the user as innovator strategy and other strategies like company transformation and open innovation can yield to the creation of blue oceans, it is obvious that such a case can create a very strong competitive advantage for the company in question.

Creating a competitive advantage was always the holy grail of all companies regardless the kind of markets they were operating into. In our contemporary times, with the globalization changing the way marketers and strategies are thinking, new ways of developing such advantage have come into consideration.

Also, multinational companies operating in the contemporary globalized environment need to adapt to changes in a fast changing world. External crisis, may create significant problems that might jeopardize their even existence. Confronting an external crisis, on the other hand, may actually lead surviving multinationals to innovate, something which is a vital factor in terms of achieving their organizational renewal (Martin-Rios \& Parga-Dans, 2016). 
Changing is extremely important, especially nowadays. It is also very important that multinational companies need to be extroverted in order to exchange ideas, knowledge and technology with other companies and people outside their safety zone. This extroversion can lead to innovation, which accordingly can lead to transformation thus strategy renewal.

Multinational firms nowadays have a very important role to play in all countries' economies and in international relations between countries. They can bring thru investment a substantial gain to both the local communities and their home countries (Lorena, 2017). This fact per se, means that multinationals' survival is a very important aspect of global economy and need to be treated in a very sensitive way. Strategy renewal can create blue oceans, which accordingly can help multinational companies to overcome their problems and achieve sustainable development.

Many aspects of the issue did not stressed in this paper which tried to shade some light into the connection between the creation of blue oceans via the company strategic transformation and innovation in mainly two forms, the customers as innovators one and the open innovation via the literary review path. A future research will probably include aspects like how such a correlation differentiates from industry to industry or how it appears, if it does, in emerging and developing markets.

\section{References}

1. Agarwal, R. \& Helfat, C.E. (2009). Strategic Renewal of Organizations, Organization Science, 20(2), 281-293.

2. Amankwah-Amoah, J., Ottosson, J., Sjögren, H., Linköpings universitet, Filosofiska fakulteten, Institutionen för ekonomisk och industriell utveckling \& Nationalekonomi 2017; 2016; "United we stand, divided we fall: historical trajectory of strategic renewal activities at the Scandinavian Airlines System, 1946-2012", Business History, 59(4), 572-35.

3. Binns A., Harreld J.B., O’Reilly C., Tushman M.L. (2013). The art of strategic renewal [online]. MITSloan Management Review. Available at: https://sloanreview.mit.edu/article/the-art-of-strategic-renewal/ (Accessed 28.03.2018).

4. Block, J.H., Henkel, J., Schweisfurth, T.G. \& Stiegler, A. (2016). Commercializing user innovations by vertical diversification: The user-manufacturer innovator, Research Policy, 45(1), 244-259.

5. Claytonchristensen.com, n.d. Disruptive innovation [online]. Available at: http://www.claytonchristensen.com/key-concepts/ [Accessed 16.3.18].

6. Floyd, S.W. \& Lane, P.J. (2000). Strategizing throughout the Organization: Managing Role Conflict in Strategic Renewal, The Academy of Management Review, 25(1), 154-17.

7. Huizingh, E.K.R.E. (2011). Open innovation: State of the art and future perspectives, Technovation, 31(1), $2-9$.

8. Kankanhalli, A., Ye, H. \& Teo, H.H. (2015). Comparing Potential and Actual Innovators: An Empirical Study of Mobile Data Services Innovation, MIS Quarterly, 39(3): 667.

9. Kim, W.C. \& Mauborgne, R. (2005). Blue ocean strategy: how to create uncontested market space and make the competition irrelevant, Harvard Business School Press, Boston, Mass.

10.Kim, W.C. \& Mauborgne, R. (2005). Blue Ocean Strategy: From Theory to Practice, California Management Review, 47(3), 105-121.

11.Lorena, D.P. (2017). The expansion of multinational companies globally, Analele Universităţii Constantin Brâncuşi din Târgu Jiu : Seria Economie, 2, 102-107.

12.Luthje, C., von Hippel, E. \& Herstatt, C. (2005). User-innovators and "local" information: The case of mountain biking, Research Policy, 34(6), 951-965.

13.Markides, C. (2006). Disruptive Innovation: In Need of Better Theory, Journal of Product Innovation Management, 23(1), 19-25.

14.Martin-Rios, C. \& Parga-Dans, E. (2016). Service response to economic decline: Innovation actions for achieving strategic renewal, Journal of Business Research, 69(8), 890-2900.

15.Mortara, L. \& Minshall, T. (2011). How do large multinational companies implement open innovation? Technovation, 31(10), 586-597.

16.Nordlund, H., Lempiala, T. \& Holopainen, M. (2011). Openness of innovating: the new roles of customers and users in business-to-business context, International Journal of Entrepreneurship and Innovation Management, 14(4), 282.

17.Ogawa, S. \& Pongtanalert, K. (2013). Exploring Characteristics and Motives of Consumer Innovators: Community Innovators vs. Independent Innovators, Research Technology Management, 56(3), 41. 
18. Oliveira, P. \& von Hippel, E. (2011). Users as service innovators: The case of banking services, Research Policy, 40(6), 806-818.

19.O'Reilly, C. \& Tushman, M. (2016). Lead and Disrupt: How to Solve the Innovator's Dilemma, Stanford Business Books, Palo Alto.

20.Pongtanalert, K. \& Ogawa, S. (2015). Classifying user-innovators - An approach to utilize user-innovator asset, Journal of Engineering and Technology Management, 37, 32-39.

21.Schmitt, A., Raisch, S. \& Volberda, H. (2016; 2018). Strategic Renewal: Past Research, Theoretical Tensions and Future Challenges, International Journal of Management Reviews, 20(1), 81-98.

22.Thomke and Von Hippel (2002). Customers as innovators. A new way to create value [online] Hbr.org. Available at: https://hbr.org/2002/04/customers-as-innovators-a-new-way-to-create-value (Accessed 16.3.2018).

23.Von Hippel, E. (2005). Democratizing innovation. MIT Press. USA.

24.Zhexembayeva, N. \& Books24x7, I. (2014). Overfished ocean strategy: powering up innovation for a resource-deprived world, First;1;1st; edn, Berrett-Koehler Publishers, Oakland. 